\title{
JOURNAL.RU
}

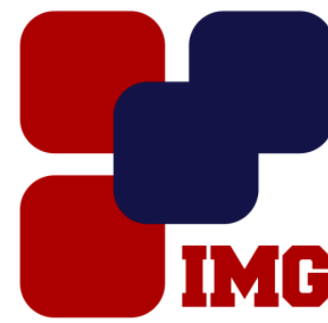

IVANOY
Management
GROUP

Диль Н.В.

АСА ДГТУ

Ростов-на-Дону, Россия

doi: $10.18411 / 1 \mathrm{j}-31-07-2017-15$

idsp 000001:1j-31-07-2017-15

\section{Проектирование общественных зданий и сооружений для маломобильных групп населения}

В современном обществе должны существовать равные возможности для всех групп населения. Мало кто задумывается о том, что большинство общественных зданий и сооружений не приспособлены для маломобильных групп, которые разделяют на два вида:

- маломобильные группы, имеющие инвалидность

- маломобильные группы, не имеющие инвалидность (беременные женщины, временно нетрудоспособные, люди с детскими колясками, лица преклонного возраста (60 лет и старше), дети дошкольного возраста, люди с тяжелыми тележками).

К этим категориям относятся достаточно большое количество граждан. Поэтому необходимо образовать такую среду, в которой все группы населения смогут без препятствий пользоваться разноплановыми услугами общественных зданий, не требуя при этом помощи других. То есть следует создать без барьерной среду. Без барьерная среда- это среда, которая позволяет людям с особыми потребностями вести независимый образ жизни, осуществлять различные связи между внутренней и наружной средой.

При строительстве зданий и сооружений необходимо уделять внимание входной группе. На законодательном уровне определенно, что различные здания должны быть оснащены пандусами или подъёмными механизмами. По правилам уклон пандуса не следует превышать 10\%. Поверхность пандусов и ступеней необходимо оборудовать поручнями. Их устраивают на 0,7 и 0,9 метров. Они 
должны быть непрерывные по всей высоте. Оснастить основание пандуса тактильным антискользящим покрытием. Возле предусмотреть разворотные площадки для инвалидных колясок не менее чем 1,5м на 1,5м, а в районахактивного использования не менее чем 2,1м на 2,1м. Для возможности проезда порог возле двери должен быть не более чем 0,025м. Внутреннее пространство необходимо снабдить опорными поручнями, которые устанавливают в соответствии со строительными нормами и правилами. Марш открытой лестницы допускается не более 12 ступеней и не менее 3 . К тому же завершающие части поручня должны быть длиннее марша на 0,3м. Так женеобходимо обеспечить санитарно-гигиенические места для без барьерного посещения маломобильных групп населения, которые соответствуют необходимым требованиям. По периметру сантехнического узла требуется установить поручни. С их помощью человек с ограниченными физическими возможностями сможет самостоятельно передвигаться, не прося помощи у других людей. На автостоянке необходимо расположить не менее 10\% мест, которые оборудованных специализированными знаками, которые не должны занимать другие транспортные средства.Ширина территорий для автомобиля должна быть минимум 3,5 метров. Это на 1 метр больше, чем для обычного транспорта. Обусловлено подобное увеличение тем, что пассажиру или водителю необходимо полностью открыть дверь. А также чтобы беспрепятственно сесть в машину и не создавать никому неудобств. В здании необходимо установить пассажирский лифт для людей на инвалидных колясках. Габариты лифта должны соответствовать нормам (ширина не менее 1,1м, глубина не менее 1,4м, ширина дверного проёма не менее 0,9м).

К сожалению, при строительстве и эксплуатации общественных зданий и сооружений эти нормы соблюдаются не всегда. Например, на улицах городов часто можно увидеть пандусы, которые опасны для использования и не соответствуют строительным нормам.Радует, что с каждым годом к этой проблеме уделяют все больше и больше внимания. К примеру, в общественных местах стали проектировать специальные санитарно-гигиенические комнаты, которые оборудованы поручнями и на улицах городов можно наблюдать правильно установленные пандусы.

Считаю, что важнейшей задачей архитектора состоит в том, чтобы доступными средствами архитектуры адаптировать маломобильные группы населения в общественную жизнь. Тогда произойдёт освобождение не только от «архитектурных», но и «психологических» барьеров. 
1. СП 59.13330.2012 Доступность зданий и сооружений для маломобильных групп населения.

2. СП 118.13330.2012* Общественные здания и сооружения.

3. Маилян, Сабанчиев, Щуцкий«Проектирование зданий и сооружений промышленного и гражданского назначения». 